\title{
Hobbes, Universal Names, and Nominalism
}

\section{Stewart Duncan}

Draft of 19 October 2012

Thomas Hobbes was, rather famously, a nominalist. The core of that nominalism is the belief that the only universal things are universal names: there are no universal objects, or universal ideas. Hobbes's nominalism prompted notable objections from his contemporaries. Leibniz referred to Hobbes as an ultranominalist, someone who went well beyond the position of previous nominalists, and he and other contemporaries objected that Hobbes's nominalist views would have the consequence that people could not say the same thing in different languages.

Hobbes's nominalism is prominent enough that it is regularly mentioned in accounts of his philosophy, but there is relatively little extended discussion of this topic in the secondary literature. ${ }^{1}$ However, despite the brevity of Hobbes's treatments of the issue, and the seeming clarity of his central view that universal names are the only universals, a variety of questions do arise.

This paper has three main sections. The first and longest looks at what Hobbes's views about universal names were, how they evolved over time, and how Hobbes argued for them. The remainder of the paper investigates Hobbes's view further by looking at two objections to it, one from the seventeenth century and the other from the twentieth. Thus the second section examines a criticism made by several of Hobbes's contemporaries, that Hobbes's view could not account for people saying the same thing in different languages. Then the third section looks at a more recently popular criticism of Hobbes, that his

${ }^{1}$ That said, for some discussions see Bernhardt (1985), Callaghan (2001), Jesseph (1999, 20519), Laird, (1934, 147-9), Peters (1956, 126-37), and Watkins (1965, 103-9). 
nominalism's reliance on similarity implicitly (and inconsistently) involves reliance on a universal.

\section{Hobbes's nominalism}

The central reason to call Hobbes a nominalist is that he says that universal names are the only universals: "there is nothing universal but names" (EL 5.6). ${ }^{2}$ Thus understanding his nominalism is largely a matter of understanding his view about common or universal names. There are three main textual sources for Hobbes's views about these matters. The first two are the chapters on language in the Elements of Law and Leviathan, two general accounts of the workings of language written about a decade apart. The third is the slightly later De Corpore, which contains Hobbes's longest discussions of the workings of language.

The details of the views and arguments change from text to text, but there are certain common features. Discussions of universals are situated in discussions of the distinction between proper and common names. Proper names each name one thing, but common names each name more than one thing. Those common names are, Hobbes says, the only universals. In supporting that idea, that names are the only universals, Hobbes argues that there are no universals in rerum natura, no universal things, we might say. He also argues that there are no universal ideas.

Hobbes was thus opposed to the great majority of his contemporaries on this issue. The rejection of universal things was widespread in the early modern period. However, that tended to be accompanied by an acceptance of what we might call universal ideas (though

\footnotetext{
${ }^{2}$ I give references to some of Hobbes's works using abbreviations, followed by chapter and paragraph or section numbers. EL = Elements of Law, using Gaskin's edition (Hobbes 1990); $\mathrm{L}=$ Leviathan, using Curley's edition (Hobbes 1994b); DeCo = De Corpore, using Schuhmann's edition (Hobbes 1999) and Martinich's translation of chapters 1-6 (Hobbes 1981).
} 
the terminology and the details of the views varied widely). This was true of Hobbes's seventeenth-century 'modern' contemporaries. ${ }^{3}$ It had also been true of Hobbes's most famous nominalist predecessor Ockham. ${ }^{4}$ He argued in his Summa Logicae that "it ought to be said that every universal is one particular thing and that it is not a universal except in its signification, in its signifying many things". ${ }^{5}$ Moreover, he went on to argue there that "no universal is a substance existing outside the mind", but that "every universal is an intention of the mind". As Panaccio summarizes Ockham's view: "species and genera are concepts. Which is to say they are but natural signs within the mind. Their generality does not amount to a special ontological feature they have but to a semantical one: a general concept, after all, is simply a singular mental occurrence that signifies several other singular entities" (Panaccio $2000,65)^{7}$

Hobbes sympathizes with something of the spirit of this: talk of universals such as genera is not to be explained by the existence of special universal entities that correspond to them, but by a better understanding of the semantics of the talk. And that better understanding is, for Hobbes, one in which there are only particular things, which come to represent multiple other particular things. For Hobbes, however, the particulars that do that representing are words, not concepts or anything else that exists in the mind. The mental language that plays such an important role in Ockham's account is a much less important aspect of Hobbes's story. Hobbes does say that the role of language is to make our thoughts

\footnotetext{
${ }^{3}$ See several of the other papers in this volume.

${ }^{4}$ On the comparison of Hobbes's nominalism and Ockham's, see Bernhardt (1985).

${ }^{5}$ Summa Logicae I.15; Ockham $(1998,78)$.

${ }^{6}$ Summa Logicae I.16; Ockham $(1998,79)$.

${ }^{7}$ It might seem mistaken to compare Hobbes to Ockham, on the grounds that the early moderns were engaging in different debates about universals and nominalism than their medieval predecessors were. But although Hobbes ignored or abandoned much of the apparatus of medieval discussions of language, there are still strong echoes of it. He was still, for instance, traditional enough to talk of "the five names that Porphyry expounds in his Isagoge" (Hobbes 1994a, 108).
} 
known, talking of speech, "consisting of names or appellations, and their connexion, whereby men register their thoughts, recall them when they are past, and also declare them one to another for mutual utility and conversation" ( $L$ 4.1) This suggests perhaps that there is a sort of mental language that is translated into an external one. ${ }^{8}$ But our power of thought would, in Hobbes's picture, be severely limited if we lacked public/external language. In particular we would lack the power of universal expression, indeed cognition, which is only enabled by language. ${ }^{9}$

\section{1a. The Elements of Law (1641)}

Already by the early 1640s Hobbes believed that there were no universal things, only universal names. In chapter 5 of the Elements of Law, having introduced names, Hobbes distinguishes between universal and singular names: singular names name one thing, while universal names name more than one thing. ${ }^{10}$ As examples of singular names Hobbes gives 'Socrates' and 'he that wrote the Iliad', so definite descriptions count as names. As an example of a universal name he gives 'man', which is a name given 'to every particular of mankind" (EL 5.5), that is, to every individual man.

Having distinguished the two sorts of name, Hobbes goes on to note that some people have thought there to be universal things, as a result of noticing that there are universal words (EL 5.6). On this view

besides Peter and John, and all the rest of the men that are, have been, or shall be in the world, there is yet somewhat else that we call man, (viz.) man in general,

\footnotetext{
${ }^{8}$ For a useful discussion of Hobbes on mental language, see Pécharmann (1992). For a reading of Hobbes that emphasizes the importance of "mental discourse", see Hacking $(1975,15-25)$.

${ }^{9}$ It is therefore misleading to say that "Hobbes's view about what is a universal is orthodox Ockhamism" (Martinich 1981, 357).

${ }^{10}$ On Hobbes's views about the signification of singular names, see Duncan (2011).
} 
deceiving themselves by taking the universal, or general appellation, for the thing it signifieth (EL 5.6).

On this view there is some sort of universal thing man, as well as the universal name 'man'. But this view is, Hobbes thinks, wrong. The name is universal, but the thing signified is not universal, for there are no universal things to signify. ${ }^{12}$

In support of his view, Hobbes imagines someone asking a painter for "the picture of a man, which is as much as to say, of a man in general" (EL 5.6). All that is being asked for, Hobbes says, is a painting of some man or other. There is no other thing, man in general, of which one wishes a picture. Hobbes's opponents might however handle the example without much difficulty. To ask for a picture of a man, they might say, is just to ask for a picture of some man or other. There is another thing, the universal man, but it is not what 'paint me a picture of a man' is asking for a picture of. You might do that with another request: 'paint me a picture of the universal man'. But we don't do that, perhaps just because the universal man is not the sort of thing that can be pictured.

Hobbes frames this discussion in Elements of Law 5.6 in a somewhat limited way. The existence of universal names "hath been the cause that men think" that there are universal things. Thus Hobbes is trying to undermine a certain motivation for a sort of realism about universals. The realists can find a way to deal with his particular example. But still, he might ask, why should we ever get to the point of believing and defending the view that there are universal things? What is the good initial motivation ${ }^{13}$

\footnotetext{
${ }^{11}$ Hobbes leaves it rather vague what sort of view he had in mind to oppose. The most obvious candidate though is the 'realism' of scholastic Aristotelian debates.

${ }^{12}$ In this text Hobbes appears to talk interchangeably of naming and signifying.

${ }^{13}$ This would presume of course that realism requires motivation, and is not the default to which we should return, absent other motivation.
} 
In the background of Hobbes's discussion - and underlying his doubts about motivations for realism - is, perhaps, his basically imagistic view about thought. If we think using images that resemble the objects thought about, then there will be no way to think about something of which we can produce no resembling image. So there will be no way to think about any alleged universal object that cannot be pictured. And if you thought this, you might consider using it as the basis of an argument against belief in such things. It might go as follows: we can only think using images; but we can have no image of alleged universal objects; so we cannot think of alleged universal objects; but you should not believe in things you cannot think about; so you should not believe in universal objects. ${ }^{14}$ Such an argument for nominalism is not explicit this text. But Hobbes's thinking along these lines would explain why he thinks that the example of what can be painted should persuade us that there are no universal things, only universal names. A painting that resembles the painted object is not, for Hobbes, just one example of representation. Rather, it is an example that is very much like the most basic sort of mental representation, mental images resembling the things they represent. ${ }^{15}$

Related to that, it is notable and curious that there is no argument against universal ideas here. Indeed is not completely clear, from The Elements of Law alone, that Hobbes was by this point committed to the denial of universal ideas. That said, just as there is no argument against them, there is also no explicit acknowledgment of their existence. An

\footnotetext{
${ }^{14}$ That argument works similarly to the way in which it is sometimes suggested Hobbes argued for materialism, starting from the fact that unextended incorporeal objects cannot be pictured. See Duncan (2010) on Leibniz reading Hobbes this way, and Duncan (2012) on Locke understanding materialists as arguing this way. On the nominalism-materialism connection, see also Zarka (1985).

${ }^{15}$ Hobbes does allow that there is at least one of thinking about things that does not involve resembling images this is the point of his repeated story about how we can think about God as the cause of the world, by analogy with the way in which a man born blind can think of fire as the case of heat (Descartes 1984, 2.127, Leviathan 11.25).
} 
imagistic argument might perhaps, indeed, be extended to provide an argument against universal ideas, as well as against the universal things that are his explicit target. Hobbes appears to have believed that representation was resemblance, showing this with his argument that that there is no idea of God, because we have no image of him. ${ }^{16}$ So one might think it was open to Hobbes to argue that there is no universal idea man. Pictures of men all resemble particular men. There is no universal image that resembles men in general, without resembling any particular one. So there is no such mental image, no such idea. Mind you, that is far from a watertight argument. If nothing else, we should note that one image can resemble more than one thing. A picture of a black cat might well look like several black cats, and thus be said to represent them, given a resemblance theory of representation. If a physical picture can do that, why not a mental one? And if a mental picture can do that, why can it not function as a universal idea? Even with a theory of ideas based on images and resemblance, there appears to be room for universal ideas. ${ }^{17}$

\section{1b. Other texts of the $1640 \mathrm{~s}$}

Though the Elements of Law was Hobbes's one systematic work of philosophy of the 1640s, there are other works of the time in which he discussed the relevant workings of language. ${ }^{18}$ For example, Hobbes briefly presented his nominalist view in a 1641 letter to Mersenne. There he says that

\footnotetext{
${ }^{16}$ See the Third Objections, and Duncan (2005). The imagism was persistent, not just a feature of the Third Objections. Thus Hobbes wrote to Mersenne in 1648 that "This little book also contains some expressions which do not produce any mental images of things..." (Hobbes1994a, 167).

${ }^{17}$ See Laird (1934, 147).

${ }^{18}$ Hobbes did publish part of his Elements of Philosophy in the 1640s (De Cive) but the other two parts did not appear for several more years.
} 
one must know that although the name 'man' is a common name (one, in fact, of the five names that Porphyry expounds in his Isagoge), every man is either Peter or Socrates or some other individual ... Socrates and man are not two men, nor two things, but one man described by two names (since it is the same thing which is named 'Socrates' and named 'man') (Hobbes 1994a, 108).

That is, the objects named by 'man' are all individuals. There is no universal object man, though there is a universal name. This is the same line as taken in the Elements of Law: acknowledging the existence of universal names, and denying the existence of universal objects that correspond to them. The letter again leaves open, however, the question of the existence of universal ideas of some sort.

Another useful source is Chatsworth manuscript A10 (Hobbes 1973, 463-513), which has sometimes been thought to be Hobbes's own work, but which Malcolm (2002, 99-101) has argued is in fact a set of Robert Payne's notes on Hobbes's work. ${ }^{19}$ This text thus needs to be treated carefully, especially in its details. But it does appear, in one way or another, to be a source of information about what Hobbes thought at this time. And it contains the following highly relevant passage.

Common names are attributed to many things, proper names to single things. Common names, as they are the names of many things one by one, not taken collectively, are called universals.

Therefore a universal is a name, not some thing existing in rerum natura, or a phantasm of something formed in the soul. A universal is a word, or a name of

\footnotetext{
${ }^{19}$ On the dating of the text, see Malcolm (2002, 101-3).
} 
names. Thus when animal is said to be universal, it is the name itself that is universal, and 'animal' does not signify some universal thing. ${ }^{20}$

Here we see, as in The Elements of Law, the observation that there are universal names, and the denial that there are any corresponding universal things. We also find something new, the denial that there is any universal phantasm (or idea).

We also see here, perhaps, the suggestion of an argument for Hobbes's view, as the denial of universal things and ideas is apparently supposed to follow somehow from the views in the first paragraph. There are two ways in which we might understand the connection between the two paragraphs. One is just to take Hobbes to be pointing out that if his view that common names are the only universals is correct, then alternative views that countenance universal ideas, or universals in rerum natura, must be mistaken. That is no doubt a helpful thing to have clarified, but clarifying it gives us no particular reason to believe Hobbes's view. Alternatively, perhaps we might see more of an argument here. But why might common names being "the names of many things one by one, not taken collectively" show us that there are no universal ideas or things? After all, that observation alone does not rule out the existence of universal ideas or things. Perhaps there is a sort of appeal to simplicity here. We know that there are common or universal names. If we see that they work as Hobbes says they do - naming each and every one of the several things that they apply to, not the collection of them or any other single thing - we will see that we can

\footnotetext{
${ }^{20}$ Hobbes (1973, 465), my translation. In the original: "Nomen est, commune, quod pluribus rebus; proprium, quod rei singulari, attribuitur. Commune, cum sit plurium rerum singillatim, non collective sumptarum nomen, universale dicitur.

"Est igitur nomen hoc universale, non rei alicujus in rerum natura existentis neque ideae, sive phantasmatis alicujus in animo formati; sed alicujus vocis, sive nominis nomen. Sic cum animal dicatur universal, non res aliqua voce universalis significata, sed imsum nomen animalis est universale".
} 
explain the phenomena of language with reference to only the things that everyone already agreed existed, without needing to suppose or appeal to extra things.

\section{1c. Leviathan (1651)}

Chapter 4 of Leviathan provides another discussion of names. Again Hobbes distinguishes proper or singular names from common or universal names. Singular names are each the name of one thing, while common names are each the names of many things. ${ }^{21}$ And again Hobbes says that names are the only universal things. A common name names several things:

some [names] are common to many things; as man, horse, tree; every of which, though but one name, is nevertheless the name of divers particular things; in respect of all which together it is called an universal, there being nothing in the world universal but names; for the things named are every one of them individual and singular ( $L$ 4.6). In Leviathan we have, then, a restatement of the view that names, not things, are universal. With the statement that there is "nothing in the world universal but names" we also have a clear denial of universal ideas, as well as of universal things.

In addition, Hobbes says a little about why a universal name is imposed on those things it is imposed on. The reason lies in a similarity between those named things.

One universal name is imposed on many things, for their similitude in some quality, or other accident: and whereas a proper name bringeth to mind one thing only; universals recall any one of those many (L 4.7)

\footnotetext{
${ }^{21}$ Universal names are said in L 4.6 to name many things. In L 4.9 the extent of application of different terms is described in terms of larger signification. This appears to be another case in which signification language is used interchangeably with naming language.
} 
This view will be important in later discussions, for here we find both some barrier against the view that all use of language in Hobbes's picture is completely arbitrary, and we also find the reason why some have thought there is a hidden universal in Hobbes's system.

\section{1d. Common names in De Corpore}

There is yet another account of common or universal names in chapter 2 of De Corpore. In that chapter, Hobbes argues that names are signs of conceptions, but names of things (DeCo 2.5-6). The thing named is often a body, but could also be an accident, a phantasm, a name, or another piece of language (a speech). After laying out these views, Hobbes works through a variety of distinctions between kinds of names, such as positive and negative, first intention and second intention, and absolute and relative.

Among the distinctions discussed is that between common and proper names (DeCo 2.9). The distinction is made in a way very similar to that in which it was made in previous texts. Common names name many things, whereas proper names name only one thing. But, because a common name is the name of many things taken one by one but not of all things collectively at the same time (as 'man' is not the name of the human race, but of each member, such as Peter, John and the other men separately) it is called universal for that reason. Therefore the name "universal" is not the name of some thing existing in nature, nor of an idea or of some phantasm formed in the mind, but is always the name of some vocal sound or name (DeCo 2.9). ${ }^{22}$

\footnotetext{
22 "Nomen autem commune, cum sit plurium rerum sigillatim sumptarum nomen, non autem collective omnium simil (ut homo non est generis humani nomen, sed uniuscujusque ut Petri, Johannis, et caeterorum hominum seorsim), vocatur ob eam rem universale. Est ergo nomen hoc universale non rei alicuijus existentis in rerum natura neque ideae sive phantasmatis alicujus in animo formati, sed alicujus semper vocis sive nominis nomen". I depart from Martinich (1981)'s translation in beginning the passage "But, because" rather than
} 
Here we have perhaps Hobbes's clearest statement of the view that only names are universal, and that no idea, and no other thing, is universal. We also have a suggestion of an argument, very similar to the suggestion of one that was seen in manuscript A10. In both cases, we are first told that universal names are names of several things singly, but not of the collection of them. Then we are told that, therefore (igitur, ergo) names are the only universals, and there are no universal ideas, or universals in rerum natura.

As with the passage from the earlier manuscript, there appear to be two ways one might understand this connection between claims in Do Corpore. One involves Hobbes simply making explicit a consequence of his view: if only names are universal, then neither ideas nor anything else is universal. Alternatively, perhaps this is supposed to be more of a persuasive argument than a clarification. But again, how might this go? Well again, we might speculate that Hobbes is offering a sort of argument from simplicity of explanation. If this is how universal names work, there is no need to suppose there are universal ideas or things in order to explain the phenomena of language. If 'horse' names this horse and that horse, etc., why suppose there are universal horses in the mind or elsewhere? The only reason to suppose they existed, one might suspect, was to give 'horse' something to name. But we already believe in the horses themselves, and they turn out to be what 'horse' names.

If that is what Hobbes was arguing - and it is far from explicit that he was - how persuasive might it have appeared, and how ought we to judge it? Hobbes's audience was full of people who rejected universals in rerum natura, so his arguing for that rejection would have been unsurprising, if hardly novel. The rejection of universal ideas would have been more controversial. Indeed, they might have looked like something we know by experience to exist, not like a theoretical postulate that could be rejected as unnecessary. Thinking that

“Moreover, when". It's not that some common names sometimes work in the way described - rather, this is the way that they all work in general. 
way, then even if the universal idea horse is not the thing named by 'horse', we still have good reason to believe there is such an idea. Hobbes, of course, rejects that, even if his argument being discussed here does not give others much reason to follow him in doing so. And the text of De Corpore continues with what may be Hobbes's most explicit argument against universal ideas.

\section{1e. Another argument in De Corpore}

In the continuation of the above passage from De Corpore, Hobbes explicitly considers the issue of what there is in our minds corresponding to common names. There are, he says, “conceptions answering to" universal names in our minds, though as in Leviathan common names are not said to signify those conceptions. The conceptions answering to 'animal', for instance, are "images and phantasms of individual animals". When we hear a universal name, "we remember that vocal sounds of this kind sometimes evoked one thing in the mind, sometimes something else". ${ }^{23}$ So when a common name is used it brings an idea of an animal to mind, and at different times it might well bring different ideas to mind. Sometimes when I hear 'animal' I think of this cat, sometime I think of that giraffe. The most important point for Hobbes, perhaps, is that there is no universal idea that is brought to mind (or signified, or denoted, or named) by 'animal'. Nor indeed is an idea of a universal object brought to mind. Rather, only particular ideas of individual things come to mind. When we use a universal name, all we think about are particular things, giving us reason to think that aside from the name there are only particular things.

\footnotetext{
${ }^{23}$ More fully: "voces eas animal, saxum, etc. esse nomina universalia, id est, nomina pluribus rebus communia, et respondentes ipsis in animo conceptus sunt singularium animalium vel aliarum rerum imagines et phantasmata. Ideoque non est opus ad vim universalis intelligendam alia facultate quam imaginativa, qua recordamur voces ejusmodi modounam rem, modo alism in animo excitasse".
} 
Why should one agree that no universal idea is brought to mind? Hobbes seems to appeal to experience and introspection. If you think, he says, of what comes to mind when you hear the word 'animal', you will realize it is only the idea of some animal or other. But why not suspect that, sometimes at least, the universal idea of animal comes to mind? Certainly that is not visualized, as one might mentally picture some particular animal. But its not being visualized is only a problem if you think that visualization, and more generally imagination, is all there is to the world of ideas. So Hobbes might well be appealing to experience, but that appeal is bolstered by his commitment to an imagistic, imagination based, account of out mental life.

What are particular and universal ideas in this discussion? What exactly is Hobbes denying? Each idea after all is particular, one particular state of one person's mind. ${ }^{24}$ Any distinction between particular and universal ideas will have to be made in terms of what and how the ideas represent. Certainly Hobbes thinks there are no ideas that represent universal objects, because there are no universal objects. But the denial of universal ideas means more than that - to use a certain terminology, Hobbes is denying conceptualism as well as realism. In Hobbes's view, the name is associated with ideas, but only with particular ideas of particular things. There is no special sort of idea that is associated with general names but not with proper ones. ${ }^{25}$

One might suspect that Hobbes's argument here is grounded in his imagism, like the argument in the Elements of Law. In discussing his views there I noted (see section 1a above)

\footnotetext{
24 "In the first sense a particular is that which is one and not many. Those who hold that a universal is a certain quality residing in the mind which is predicable of many (not suppositing for itself, of course, but for the many of which it is predicated) must grant that, in this sense of the word, every universal is a particular" (Summa Logicae 1.14, 78; Ockham 1998, 77-8).

${ }^{25}$ Contrast for example Locke's claim that each general word is "a sign of an abstract Idea in the mind" (Locke 1975, 3.3.12).
} 
the possibility that one image - and thus one mental image - might resemble and represent multiple things. Hobbes however explicitly denies this in De Corpore: "they err ... who say that the idea of some thing is universal, as if there might be in the mind an image of some man which is not that of any one man, but of man simpliciter; but this is impossible, for every idea is both one and of one thing" (DeCo 5.8). The denial of universal ideas is here: every idea is an idea of one thing. However, though it is clear that Hobbes thought this, it is not so clear why he did, and whether his view had the resources to support it. If representation is resemblance, then he needs some way to rule out one image's resembling (well enough), and thus representing, more than one thing. How that is to be done is apparently left unsaid. ${ }^{26}$

As we have seen, Hobbes seems to argue from his views about ideas to his nominalism. However, Hobbes goes on in De Corpore 2.9 to argue in more or less the opposite direction, from his nominalism to there being only the imagination: because the conceptions we have that relate to general names are only particular ones, then there is no need to appeal to any faculty other than the imagination here. Thus he says: the conceptions answering to those things [universal names] in our minds are the images and phantasms of individual animals or other things. And for this reason there is no need to understand the force of a universal with any faculty other than the imaginative one, by which we remember that vocal sounds of this kind sometimes evoked one thing in the mind, sometimes something else (DeCo 2.9). This is in part an anti-Cartesian point, in that Hobbes takes himself to show we do not need to appeal to an ability to have intellectual insight, via clear and distinct perception, into the natures and essences of things. If universal thought, via universal names, can be explained using the imagination, Hobbes can complete his project of explaining all the workings of the

\footnotetext{
${ }^{26}$ On this problem see again Laird $(1934,147-8)$.
} 
mind on a corporeal basis, given his view of (and a fair amount of agreement about) the material basis of the imagination.

This is almost the exact opposite of using imagism about ideas to argue for nominalism. That uses the fact that we can only conceive using the imagination as a reason for nominalism. This comment in De Corpore takes the nominalism as a reason for there only being the imagination. But this and the argument of the Elements of Law show how three of Hobbes central claims fit together. His nominalism has us thinking only of particulars. His view that the imagination is the only mental faculty has us thinking only with images (which can only be of particulars, given some views about representation). And his materialism has us denying the existence of the sorts of further mental faculty that Descartes, for instance, thought must be housed in an immaterial soul.

\section{Ultranominalism}

\section{2a. Three critics of Hobbes}

Hobbes was criticized in the seventeenth century for having gone, in a problematic way, beyond nominalism. This criticism is associated with Leibniz, and his claim that Hobbes is an ultra- or super-nominalist. Consider Leibniz's "Preface to an Edition of Nizolius", where Hobbes's nominalism arises in a discussion of the nominalist principle "the simpler a bypothesis is, the better it is". ${ }^{27}$

From this principle the nominalists have deduced the rule that everything in the world can be explained without any reference to universals and real forms. Nothing is truer than this opinion, and nothing is more worthy of a philosopher of our own

\footnotetext{
${ }^{27}$ Leibniz 1969, 128. "Hypothesin eo esse meliorem, quo simpliciorem" (Leibniz 1923-, 6.2.428). This is itself offered as an explanation of the principle that "entities must not be multiplied beyond necessity", "Entia non esse multiplicanda praeter necessitatem".
} 
time. So much so that, I believe, Occam himself was not more nominalistic than is Thomas Hobbes now, though I confess that Hobbes seems to me to be a supernominalist. For not content like the nominalists, to reduce universals to names, he says that the truth of things itself consists in names and what is more, that it depends on the human will, because truth allegedly depends on the definitions of terms, and definitions depend on the human will. This is the opinion of a man recognized as among the most profound of our century, and as I said, nothing can be more nominalistic than it. Yet it cannot stand. In arithmetic, and in other disciplines as well, truths remain the same even if notations are changed, and it does not matter whether a decimal or a duodecimal number system is used. ${ }^{28}$

Leibniz makes more than one point here. Hobbes, he says, has gone beyond the views of earlier nominalists: thus "super-nominalist". ${ }^{29}$ Leibniz is clearly concerned that Hobbes's view is too conventionalist, such that "the truth of things ... depends on the human will". And he also makes the - presumably related - critical point that "truths remain the same even if notations are changed".

Though that sort of criticism of Hobbes's nominalism is most famously associated with Leibniz, we can find very similar points in the works of earlier critics of Hobbes, namely Descartes and More. All three agree in thinking that Hobbes's view can be shown to be mistaken by reflecting on the fact that we can say the same thing in different languages. Descartes's version of this criticism is found in his 1641 Replies to Hobbes's Third Set of Objections to the Meditations.

${ }^{28}$ Leibniz 1969, 128. The final two sentences were added by Leibniz in a handwritten note to his printed copy (see Leibniz 1923-, 6.2.398). "Sed quae tamen stare non potest. Uti in Arithmetica, ita et in aliis disciplinis manent eaedem veritates etsi notae mutentur, nec refert decadica, an duodenaria progressio adhibeatur" (Leibniz 1923-, 6.2.429).

${ }^{29}$ On Leibniz's claim of ultranominalism, see among others Bolton (1977) and Hübener (1977). 
As for the linking together that occurs when we reason, this is not a linking of names but of the things that are signified by the names, and I am surprised that the opposite view should occur to anyone. Who doubts that a Frenchman and a German can reason about the same things, despite the fact that the words that they think of are completely different? And surely the philosopher refutes his own position when he talks of the arbitrary conventions that we have laid down concerning the meaning of words. For if he admits that the words signify something, why will he not allow that our reasoning deals with this something which is signified, rather than merely with the words? And surely on his account, when he concludes that the mind is a motion he might just as well conclude that the earth is the sky, or anything else he likes (Descartes 1984, 2.126).

Descartes is here responding to the following curious passage in Hobbes's Objections: Now, what shall we say if it turns out that reasoning is simply the joining together and linking of names or labels by means of the verb 'is'? It would follow that the inferences in our reasoning tell us nothing at all about the nature of things, but merely tell us about the labels applied to them; that is, all we can infer is whether or not we are combining the names of things in accordance with the arbitrary conventions which we have laid down in respect of their meaning. If this is so, as may well be the case, reasoning will depend on names, names will depend on the imagination, and imagination will depend (as I believe it does) merely on the motions of our bodily organs; and so the mind will be nothing more than motion occurring in various parts of an organic body (Descartes 1984, 2.125-6).

Hobbes here suggests several views he explains in more detail elsewhere: that much reasoning requires language; that language involves propositions that have the basic structure 
' $\mathrm{A}$ is $\mathrm{B}$ ', where ' $\mathrm{A}$ ' and ' $\mathrm{B}$ ' are names; and that we can explain the workings of the mind without reference to an incorporeal intellect if we properly understand what imagination and language can do. Mixed in with that, however, is the view that much of reasoning is arbitrary, because the use of names is arbitrary. This is a view that could be controversial or trivial, depending on how it is understood. Moreover, there is a good question as to how the various claims are supposed to be linked in the passage. ${ }^{30}$ What exactly is an argument for what?

Descartes makes two points in response to Hobbes's claim. One is that we are still reasoning about things, not just names, even though we are using names to think about things. The other involves the example of the Frenchman and the German. They can talk and reason about the same things, despite their use of different words, which is in some sense arbitrary. Descartes thinks, however, that Hobbes must deny that they can reason about the same thing.

A similar line of criticism is present in Henry More's 1659 Immortality of the Soul. He too finds it a strange and problematic consequence of Hobbes's views that people talking in different languages cannot say the same thing. In the passage below, More attacks the Hobbesian view that we can explain the workings of the mind using only imagistic thought and the power of language, thus needing to appeal to no faculty other than the (corporeal) imagination.

Here Mr. Hobbs, to avoid the force of this Demonstration, has found out a marvelous witty invention to befool his followers withall, making them believe that there is no such thing as these Secundae Notiones, distinct from the Names or Words whereby they are said to be signified; and that there is no perception in us, but of

\footnotetext{
${ }^{30}$ A significant part of the examination of Hobbes's nominalism in Bolton (1977) is structured round how to understand Hobbes's argument here.
} 
such Phantasmes as are impressed from externall Objects, such as are common to Us and Beasts: and as for the Names which we give to these, or the Phantasmes of them, that there is the same reason of them, as of other Markes, Letters, or Characters, all which coming in at the Senses, he would beare them in hand that it is a plain case, that we have the perception of nothing but what is impressed from corporeall Objects. But how ridiculous an Evasion this is, may be easily discovered, if we consider, that if these Mathematicall and Logicall Notions we speak of be nothing but Names, Logicall and Mathematicall Truths will not be the same in all Nations, because they have not

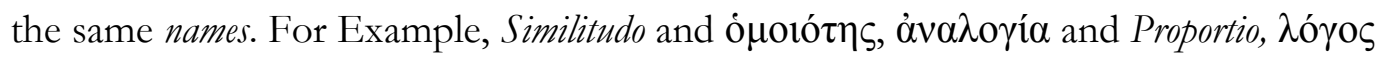
and Ratio, these names are utterly different, the Greek from the Latine; yet the Greeks, Latines, nor any Nation else, doe vary in their conceptions couched under these different names: Wherefore it is plain, that there is a setled Notion distinct from these Words and Names, as well as from those corporeall Phantasmes impressed from the Object; which was the thing to be demonstrated (More 1659, 133-4).

Hobbes argues that our thought can be explained in terms of phantasms (mental images) and names. Such a view, More objects, cannot account for the fact that Latin and Greek geometers are talking about the same thing when they are talking about proportion, for instance. They do not possess the same sensory images or corporeal phantasms. And they do not use the same words. Their ability to talk about the same thing is explained by the presence in their minds of another sort of thing, a notion. ${ }^{31}$ The Greek and Latin geometers have the same notion, which is related to each of their different vocabularies.

\footnotetext{
${ }^{31}$ Compare also the concepts of common reasons invoked by Ward in response to Hobbes (Jesseph 1999, 217).
} 
Sometimes we want to say that speakers of the same language are saying the same thing, or talking about the same thing. On at least one occasion, as Descartes noted in the Third Objections, Hobbes appeared to deny this. Leaving that possible denial aside for now, one might wonder, as Leibniz and More did, about how Hobbes could say that those two speakers were saying the same thing. Hobbes clearly usually thought they could. Thus we sometimes find him in Leviathan using his central semantic term 'signify' to express a translation relation. Taking just one of many examples, we find him talking of "versura, which signifies taking money at usury for the present payment of interest" (L 8.12). So Hobbes generally agreed with the usual view that speakers of different languages could say the same thing. But did his views about language have enough resources to explain how this could be the case? This is what More and Leibniz followed Descartes in contesting.

The passage from More shows one way in which Hobbes could have explained this phenomenon, but didn't. The French and German speakers might be using different names, but associating those names with the same notion. Thus, even in cases in which there is no external object they are both naming and discussing, and despite the obvious differences in what they say, there would be something that their talk had in common. ${ }^{32}$ But this is just the sort of thing that Hobbes denies, when he argues that there are no universal ideas. There are no universal ideas - be they of proportion or elephant. Rather there are only particular ideas of particular things, and different speakers, even of the same language, might well have different particulars in mind when using the same general name. ${ }^{33}$ Speakers of the same language at least have the name in common, but speakers of different languages lack even that. So is there really nothing that they use of language has in common, that Hobbes can

${ }^{32}$ This presumes of course that we can make good sense of different speakers possessing the same notion, presumably by possessing different token notions of the same notion type.

${ }^{33}$ Indeed, Hobbes thinks that one individual speaker need not have the same particular idea in mind each time she uses a universal name. 
point to, in order to explain how it is, on his view, that speakers of different languages can say the same thing?

Consider an example. 'Cat', 'Katze', and 'chat' are all terms for the same sort of animal, but in different languages. Is the fact that speakers of English, German, and French all appear to succeed in talking about the same animals, cats, just a giant accident, according to Hobbes? Not really. For Hobbes thinks that there are objective similarities in the world, and our grouping objects together and applying general names to them depends on recognizing those similarities. As he puts the point in Leviathan, a "universal name is imposed on many things, for their similitude in some quality, or other accident" (L 4.7). So the speakers of French, German, and English have two things in common. Their names apply to the same things, and they do so because the speakers of the three languages have all recognized the same objective similarity in the world. The same story can be told about proportions: one instance of proportion is relevantly similar to another, and speakers of many languages are recognizing this, even as they use different terms to talk about it.

\section{2b. Similarity}

On Hobbes's view, then, the application of a universal name to multiple objects is explained, at least in part, by the similarities between those objects. This view can be traced through several works.

Consider first the account in the Elements of Law. "The appellations that be universal, and common to many things, are not always given to all the particulars, (as they ought to be) for like conceptions and considerations in them all" (EL 5.7). Hobbes is here discussing equivocation. But he also has a picture of how things ought to be done. A non-equivocal word, say 'horse', is applied to all the things it is applied to, "for like conceptions and 
considerations in them all”. We see that the horses all look like one another, and as a result we give them a common name.

Something similar is said in Leviathan. "One universal name is imposed on many things for their similitude in some quality or other accident” (L 4.7). This might appear to the story a little. Whereas the Elements of Law talks about a similarity in our conceptions, that in Leviathan talks about a similarity in the objects. But in the passage from the Elements of Law, the relevant "conceptions and considerations" are said to be "in" the things the name is applied to, so perhaps Hobbes is not really, there, talking about mental representations. Moreover, knowledge of similarity of things will be based on knowledge of phantasms. And Hobbes apparently has a pretty simple conception of the relationship, such that if we judge the phantasms to be similar, we judge the objects to be similar. ${ }^{34}$

Finally, there is a related account in De Corpore, presented when Hobbes describes his distinction between positive and negative names.

The first distinction of names will be that some are positive or affirmative, others negative, which are usually called privative and infinite. Those are positive which are imposed because of the similarity, equality or identity of the things thought; those are negative which are imposed because of the diversity, dissimilarity or inequality of the things thought. Examples of the former are "man" and "philosopher," for "man" denotes any one of many men and "philosopher denotes any one of many philosophers because of the similarity of all of them. "Socrates" likewise is a positive name because what it denotes is always one and the same (DeCo 2.7).

Here of course the context is slightly different from that of the above two passages, as Hobbes is describing all positive names, including proper positive names. The role of

${ }^{34}$ See DeCo 25.8, which switches back and forth between knowing similarity of phantasms and knowing similarity of things. 
identity here relates to the case of positive proper names, and the distinction between 'Socrates' and 'not-Socrates'. Still, the relations of "similarity, equality or identity" appear to play roughly the same role that "similitude in some [...] accident" plays in the account in Leviathan. In De Corpore as in the earlier works, Hobbes thinks of common names as imposed on the objects it names because of a pre-existing similarity between the objects on which it is imposed.

There is then a consistent account in Hobbes's writings of why a common name is applied to several objects: it is because of a similarity between them. What is similarity? Hobbes addresses this issue briefly in chapter 11 of De Corpore, which looks at issues of identity and difference.

We must not, however, think about relation, as if it were an accident differing from all the other accidents of the relatum, but as one of them, namely, that [accident] with respect to which the comparison is made. For example, the similarity of one white to another white, or its dissimilarity to black, is the same accident as its white; and equality and inequality are the same accident as the magnitude of the thing compared, under different names; for that which is called white or great when it is not compared with something else, is called like, unlike, equal, or unequal when it is compared. ${ }^{35}$

On this account, the world contains (1) accidents expressed by one-place predicates, (2) the things that are the subjects of accidents, and (3) minds that make comparisons between the things. But the things themselves do not contain (4) further accidents that are their relations.

\footnotetext{
${ }^{35}$ DeCo 11.6, my translation. "De relatione non ita censendum est, tanquam ea esset accidens aliquod diversum ab aliis relati accidentibus, sed unum ex illis, nempe illud ipsum, secundum quod fit comparatio. Exempli causâ, similitudo albi cum alio albo vel dissimilitudo cum nigro est idem accidens quod albedo ejus, et aequalitas vel inaequalitas idem accidens quod rei comparatae magnitudo, sub diversis nominibus; nam quod album vel tantum vocatur, quando non comparator cum alio, idem comparatum dicitur simile, dissimile, aequale vel inaequale".
} 
Similarity is among those relations. So while Hobbes grounds the application of universal names in similarity, similarity itself is grounded in - indeed is nothing in the world in addition to - the accidents of the individual similar things.

\section{Another objection}

The above section considered an objection to Hobbes's nominalism that was common in the seventeenth century. Hobbes's views about similarity and accidents and their role in the workings of general names have prompted more recent various commentators to object that his view is inconsistent. I would like to conclude by looking briefly at this objection.

Watkins, for example, thought that Hobbes was not consistent in his nominalism, because he admitted accidents into his ontology.

He [Hobbes] not only admitted resemblances between things, but resemblances with respect to certain properties or accidents; and he said, in effect, that a common name gets extended to new objects, not arbitrarily, but in accordance with such objective resemblances (Watkins 1965, 148).

Thus, accidents play an essential role in Hobbes's system. But accidents are, Watkins thinks, a sort of universal. ${ }^{36}$ So Hobbes was inconsistent in his nominalism, because he had to accept these universals to make his view work.

This sort of criticism has been made repeatedly. There are two slightly different versions. One is the above one, that the similarity or likeness involves comparison with respect to accidents, which are universals. The other version alleges that the similarity or likeness itself is a universal: "to grant that speakers can grasp the resemblance between two

\footnotetext{
${ }^{36}$ At least, such universals play this role for "descriptive names" (Watkins 1965, 150), though with moral language there is no objective basis to counteract the ultra-conventionalist tendency in Hobbes's thought.
} 
particulars sorted under the same name seems, at a minimum, to commit the nominalist to the existence of an abstract property of similarity, likeness, or resemblance” (Jesseph 1999, 209).

In thinking about these objections, it is useful to remember that that there have been several debates and views under the heading of 'nominalism'. We have already seen this, to some degree, with Leibniz's argument that Hobbes goes (problematically) beyond Ockham. But there are other differences to note. ${ }^{37}$ The central question for Hobbes concerns the status and semantics of universal terms, with primary examples being the likes of 'man' and 'animal'. Despite Hobbes's avoidance of much of the apparatus of medieval debates about realism and nominalism, his questions and views have fairly clear connections to those earlier debates. Less immediately obvious is the connection Hobbes's view has to later debates about the status of properties or qualities.

Callaghan (2001) emphasizes the importance of seeing there are multiple debates about nominalism involved here. In a second debate, nominalism is "the rejection of properties (attributes, characters, features, qualities - the names doesn't matter)" (Callaghan 2001, 37). And in this debate too, some of the 'nominalists' try to explain things by invoking resemblance. Thus Price (1953, 7-32), for example, contrasts a Philosophy of Universals with a Philosophy of Resemblances. ${ }^{38}$ This resemblance-invoking view would seem to have connections to Hobbes's. It is a sort of nominalism, based on the resemblances between everyday objects. But the question Price is describing answers to - about the ontological

${ }^{37}$ There are yet other senses of 'nominalism' and 'universal'. The more recent use of 'nominalism' to mean the denial of abstract objects is not relevant here. For that use see for example Field (1980), which is described as a "Defense of Nominalism" because it shows it how we can have "Science without Numbers", or Burgess and Rosen (1997, 3), where a "nominalist, in the most common contemporary sense of the term" is described as "a disbeliever in abstract entities".

${ }^{38}$ For another resemblance-based nominalist answer in this second debate, see RodriguezPereyra (2002). 
status of recurring qualities in the world - is not the question that Hobbes was directly addressing when presenting his nominalism. Whereas Hobbes is primarily worried about the semantics of kind terms, and focuses on examples such as 'man', Price is primarily worried about the nature of qualities, and focuses particularly on colours. One might try to collapse one debate into the other, either by insisting that one's story about the quality of redness must also apply to a quality of humanity, or by insisting that the kind of red things is a kind to which the story about horses must also apply. But neither of those moves is obviously correct.

How is this distinction between debates relevant to the objections made to Hobbes's view by Watkins and others? Well, Hobbes is addressing the first debate, but the objection is considering Hobbes's views in the terms of the second debate. Hobbes is said to be an inconsistent nominalist because he believes in accidents, which are universals. But they are universals in the terms of the second debate, about the status of qualities, not the debate that Hobbes was explicitly addressing. Thinking in terms of the second debate gives rise to the two versions of this objection to Hobbes. One might note that he believes in accidents without attempting to reduce them to resemblances, and conclude he was not a nominalist. Or one might acknowledge some attempt in Hobbes's system to explain things in terms of similarity, but think that the similarity on which this depends is itself a universal. ${ }^{39}$ Either way, in the terms of the second debate, there is a lingering universal in Hobbes's system. But that second debate was not the debate Hobbes was addressing. It is no coincidence that Hobbes himself did not refer to accidents as universals, and showed no signs of having thought that accidents (nor, indeed, similarity or likeness) were, in a sense he cared about,

\footnotetext{
${ }^{39}$ This relates to an objection that Russell made to nominalist views that invoke resemblance in chapter 9 of The Problems of Philosophy (Russell 1990, 95-7). Rodriguez-Pereyra (2002, 10523) is one nominalist attempt to respond to that criticism, discussed by MacBride (2004).
} 
universals. And Callaghan says, "it is not entirely clear that someone who rejects properties [in the debate Hobbes was in] is thereby bound ... to reject universals [in the other debate]" (Callaghan 2001, 37). Given this distinction between the two debates, it is tempting to conclude that Hobbes's critics have confused two senses of 'nominalism'. Hobbes is being criticized for failing to be a nominalist in a sense in which he never tried to be one. ${ }^{40} \mathrm{No}$ doubt Hobbes's nominalism had its problems. But it is not at all clear that this relatively recently emphasized difficulty is one of them.

\footnotetext{
${ }^{40}$ If we must attribute to Hobbes a position in the second debate, which should it be? Various objectors, as we have seen, take Hobbes to believe in universals. But this is not necessarily correct. Callaghan (2001) argues that Hobbes was a sort of trope theorist. And we should also might consider whether one might understand Hobbes as a sort of resemblance nominalist.
} 


\section{$\underline{\text { References }}$}

Bernhardt, Jean. 1985. "Nominalime et mécanisme dans la pensée de Hobbes”. Archives de Philosophie 48, 235-49.

Bolton, Martha Brandt. 1977. “Leibniz and Hobbes on Arbitrary Truth”. Philosophy Research Archives 3, 242-73.

----. 1998. “Universals, Essences, and Abstract Entities”. In Daniel Garber and Michael Ayers (ed.), The Cambridge History of Seventeenth-Century Philosophy (Cambridge: Cambridge University Press).

Callaghan, G.K. 2001. "Nominalism, Abstraction, and Generality in Hobbes”. History of Philosophy Quarterly 18, 37-55.

Descartes, René. 1984. The Philosophical Writings of Descartes. Cambridge: Cambridge University Press.

Duncan, Stewart. 2005. "Hobbes's Materialism in the Early 1640s", British Journal for the History of Philosophy 13, 437-48.

-----. 2010. “Leibniz on Hobbes's Materialism”. Studies in History and Philosophy of Science 41, 11-8.

-----. 2011. “Hobbes, Signification, and Insignificant Names”. Hobbes Studies 24, 158-78.

-----. 2012. “Toland, Leibniz, and Active Matter", Oxford Studies in Early Modern Philosophy 6, 249-78.

Field, Hartry. 1980. Science without Numbers: A Defense of Nominalism. Princeton: Princeton University Press.

Hacking, Ian. 1975. Why does Language Matter to Philosophy? Cambridge: Cambridge University Press. 
Hobbes, Thomas. 1973. Critique du De Mundo de Thomas White, edited by Jean Jacquot and Harold Whitmore Jones (Paris: Vrin).

----. 1981. Part I of De Corpore, translated by A.P. Martinich (New York: Abaris Books).

-----. 1990. The Elements of Law, Natural and Politic, edited by J.C.A. Gaskin (Oxford: Oxford University Press).

----. 1994a. The Correspondence of Thomas Hobbes, edited by Noel Malcolm (Oxford: Clarendon).

-----. 1994b. Leviathan, edited by Edwin Curley (Indianapolis: Hackett).

----. 1999. De Corpore, edited by Karl Schuhmann (Paris: Vrin).

Hübener, Wolfgang. 1977. “Ist Thomas Hobbes Ultranominalist gewesen?” Studia Leibnitiana 9, 77-100.

Jesseph, Douglas. 1999. Squaring the Circle. Chicago: University of Chicago Press.

Laird, John. 1934. Hobbes. London: Ernest Benn.

Leibniz, GW. 1923-. Sämtliche Schriften und Briefe. Berlin: Akademie-Verlag.

-----. 1969. Philosophical Papers and Letters. Edited and translated by L. Loemker. Second edition. Dordrecht: Kluwer.

MacBride, Fraser. 2004. Review of Rodriguez-Pereyra (2002). Notre Dame Philosophical Reviews. http://ndpr.nd.edu/news/23684-resemblance-nominalism-a-solution-to-theproblem-of-universals/

Malcolm, Noel. 2002. Aspects of Hobbes. Oxford: Clarendon.

Martinich, A.P. 1981. “Translator's Commentary”, in Hobbes (1981).

More, Henry. 1659. The Immortality of the Soul. London.

Ockham, William of. 1998. Ockham's Theory of Terms: Part I of the Summa Logicae. South Bend: S. Augustine’s Press. 
Panaccio, Claude. 2000. "Semantics and Mental Language”. In Paul Vincent Spade (ed.), The Cambridge Companion to Ockham (Cambridge: Cambridge University Press) 53-75.

Pécharman, Martine. 1992. "Le discours mental selon Hobbes". Archives de Philosophie 55, $553-73$.

Peters, Richard. 1956. Hobbes. Harmondsworth: Penguin.

Price, H.H. 1953. Thinking and Experience. Cambridge: Harvard University Press.

Rodriguez-Pereyra, Gonzalo. 2002. Resemblance Nominalism: A Solution to the Problem of Universals (Oxford: Oxford University Press).

Russell, Bertrand. 1990 Problems of Philosophy. Indianapolis: Hackett. A reprint of the 1912 edition.

Watkins, J.W.N. 1965. Hobbes's System of Ideas. London: Hutchinson.

Zarka, Yves-Charles. 1985. "Empirisme, nominalisme, et materialisme chez Hobbes. Archives de philosophie 48: 177-233. 